\title{
Examination of the Parameter of Nuc Accreditation Exercise in Selected Western Nigerian Universities
}

\author{
Oribabor, O.A. PhD \\ Institute of Education, Faculty of Education, Obafemi \\ Awolowo University, ile - Ife. Osun state, Nigeria \\ bisioribabor2006@yahoo.com
}

\section{Doi:10.5901/jesr.2014.v4n6p229}

\begin{abstract}
The study examined the parameter far the National Universities Commission (NU() accreditation of programmes in four selected Nigerian universities, and evaluated the impact of the NUC's accreditation exercise on the academic programmes and administrative structures of the selected universities up to 1988.
\end{abstract}

\section{Introduction}

Therefore, the process of accreditation should provide a means of recognizing some of levels of performance, quality and integrity which engenders confidence from the public and the road educational community. A perceived belief is that accreditation is purported to provide quality assessment which is monitored by bodies assessing quality in post secondary education, including governmental agencies and professional associations. It is also believed that the process of accreditation is undertaken in order to evaluate an institution or programme against some (usually not clearly articulated) minimally acceptable standards which protect the institutions themselves, their students and the public. In this, there are two tensions. Institutions may demand that their diverse and unique character and that of their programme be maintained, despite, and in conjunction with, accreditation process. The second tension arises as government imposes more and more uniformity. For instance, the following are the goals of tertiary education as spelt out in section 6 subsection 45 of the National Policy on Education (1998)

a. Contribute to national development through high level relevant manpower training.

b. Develop an inculcate proper values for the survival of the individual and society.

c. Develop the intellectual capability of individuals to understand and appreciate their local and external environments.

d. acquire both physical and intellectual capability reliant and useful members of the society.

e. Promote and encourage scholarship and community service.

f. Forget and cement national unity; and

g. Promote national and international understanding and interaction.

Each institution is to pursue these objectives but there should be recognition by the accrediting body that there can be different and individual ways through which they could be achieved, The NUC derives its existence legitimacy, and operations from two documents. The National Policy on Education (NPE) and the NUC Decree No 16 of 1985. However, a search of the literature shows little or no previous studies focusing on how the NUC has been able to meet the objectives and public expectations contained in the documents. Since studies relevant to the accreditation functions of the NUC are almost non existent, it is necessary to review the policy on higher education as contained in the relevant sections on accreditation as stipulated by Decree No 16 of 1985. A policy as used in this work is a high level comprehensive plan embracing the philosophical, ideological goals and intended strategies for meeting some unidentifiable (multiple) challenges confronting a nation. A policy is a statement of successive probabilities and options (in the special case of education) with respect to access, equality and social justice.

\section{Public Service and Individual Satisfaction}

Shipman (1984,) drew attention to the fact that the provision of education as a universal public service has been justified because it secures the chance for talent to be develope6 wherever it occurs, Individual efforts and abilities are seen to be 
rewarded through qualification and by access to higher education and finally to prestigious and well paid employment. This is also in line with N.U.C stated objectives and curriculum.

The major flaw in this assumption regarding education has been illuminated by writers such as Boudon (1974) and Dore (1976). Boudon, using data from France, has shown that behind the failure of investment in education to reduce social inequality and increase economy opportunity lie differences in rewards, prestige and power in different occupations. Dore, looking specifically at the spread of public examination reaches similar conclusions; obtaining requires ever-increasing levels of qualification. Shipman (1985) drew attention to the fact than firstly, policies are made from information that flow up through the organization, and are implemented as instructions from down. Shipman further argues that, secondly, policies in a: educational services always need interpretation at all levels. Thirdly, the distance and time between a policy decision made at education committee and its impact in universities is always long, Ehindero (1986), and Shipman (1984),drew attention to the fact that "all evaluation Systems function to provide feedback in all educational instructional system". Ehindero opines that;

advantages of such a feedback system include clarification about

programmes objectives and identification of any discrepancy between intentions and actualizations.

Formative or process evaluation serves to guide as work progresses while summative or outcome evaluation gives a picture of what has been achieved.

In a nutshell, a policy on education provides a comprehensive frame world government's intentions and concrete proposals for the improvement of education through innovations in the stated objectives, content and the general management of education. Ideally, policy is rooted in, and reflects a nation's history, norms, values aspirations, hopes and its cumulative cultural heritage.

Research on NUC accreditation exercise in Nigeria is an important but a rather neglected area in Higher education. Several reasons may be adduced for this: lack of interest in the area by researchers, inadequate facilities and human resource including lack of vital information about the operations in NUC, misunderstanding of the relationship between the NUC and the Universities especially as it relates to the quality regulatory function of the NUC. Given the above, studies on the NUC accreditation exercise are disappointingly almost nonexistent in Nigeria. Elsewhere around the world, previous researches similar to the one being reported here is limited to quality control mechanism and then focus almost exclusively on appraising programmes effectiveness and related factors. Programme appraisal and accreditation as subsets of Quality Assurance and Control Mechanism have sometimes been confused in the literature. Liston (1999). This confusion can also be attributed to the general lack of interest in research on accreditation.

\section{Research Questions}

- What are the parameters used in the accreditation of programmes by the N.U.C?

\section{Objectives of the Study}

- Identify the parameters that are used in the accreditation of programmes in the universities.

\section{Validity and Reliability of Research Instrument}

Certain measures were face and content validity and reliability of the research instruments. The measures were put in place in order to be reasonably sure that the instruments indeed measure the variables adequately based on research objectives.

A two-stage pretesting of the instruments was carried out. The first stage was done among four senior members of the academic community, one of whom is an expert in evaluation. This stage led to the reduction of the number of items listed in the first sets of instruments developed for the two target populations.

The second stage was among 50 academics and 20 students of Obafemi Awolowo University. Analysis of the instruments revealed a reliability co-efficient $(r)$ of 0.82 and 0.86 fo the academic and students respectively using Kuder-Richardson 21 technique. 


\subsection{Reliability Estimate}

The reliability estimates of these research instruments were established using Kuder Richardson 21 technique with the assistance of experts in test and measurements. 50 lecturers and 20 students of Obafemi Awolowo University lle-Ife were involved in a pilot study for the estimation of the reliability coefficient of these instruments, The reliability coefficient of the staff questionnaire was calculated to be 0.82 , while that of the students was found to be 0.86 .

The instrument so developed and validated was administered to the targeted subjects.

In addition, information relevant to the availability, appropriateness and adequacy, of recommended and existing infrastructure and facilities required to implement the N.U.C programmes were also collected from National University Commission (NUC).

\section{Data Collection Procedure}

The data used for the study were collected from primary and the secondary sources. For the primary sources, a total of 400 questionnaires were administered among the academic and non-academic members of staff, while a total of 200 questionnaires were administered among the final year students of the selected universities. Research Assistants were employed tr the administration of the questionnaires.

Distribution and Retrieval of Questionnaires

The table below shows the breakdown of the distribution and retrieval of the questionnaires.

Table 1: Distribution (D) and Retrieval (R) of Questionnaires

\begin{tabular}{|c|c|c|c|c|c|c|c|c|c|c|}
\hline Questionnaire & \multicolumn{9}{|c|}{ Analysis } & \multicolumn{3}{c|}{ O.O.U U.N.A.D } & \multicolumn{2}{c|}{ Total } \\
\hline & \multicolumn{2}{|c|}{ O.A.U } & \multicolumn{2}{c|}{ U.I } & \multicolumn{2}{c|}{ U. } \\
\hline Staff students & D & R & D & R & D & R & D & R & D & R \\
\hline & 100 & 96 & 100 & 97 & 100 & 98 & 100 & 98 & 400 & 389 \\
\hline & 50 & 50 & 50 & 50 & 50 & 50 & 50 & 50 & 200 & 200 \\
\hline Total & 150 & 146 & 150 & 147 & 150 & 148 & 150 & 148 & 600 & 589 \\
\hline
\end{tabular}

NB: D - Distribution; H. - Retrieval

On the whole, a total of 389 and 200 completed questionnaires were collected from the staff and students respectively. This led to a response rate of $97.3 \%$ for the staff and $100 \%$ for the students.

\section{Data Analysis Techniques}

The edited questionnaires were adequately and appropriately coded. The SPSS version 9.0 was employed both for data entry and analysis. The university and vicariate analytic techniques were employed.

The univariate analysis reveals the frequency counts of the variables being measured. while the bivariate analysis shows the relationship between two variables of interest in relation to research hypothesis. The statistic x2-test of independence was employed using a level of significance of 0.05 .

\subsection{Hypotheses Testing}

All the six major hypotheses formulated for the study were tested at $95 \%$ confidence level ( 0.05 level of significance). The probability levels computed by the SPSS package were used to interpret and discuss the results of the analysis. 
Table 2: Familiarity With-Criteria/Parameters for Accrediting Programmes Philosophy and Objectless of the Programme. Curriculum, Teaching Staff Quantity And Quality, Students Admission. Retention And Graduation, Standards of Degree Examination.

\begin{tabular}{|l|c|c|c|c|c|c|c|c|c|c|}
\hline Questionnaire & \multicolumn{9}{|c|}{ University } & \multicolumn{2}{c|}{ O.O.U } & \multicolumn{2}{c|}{ U.N.A.D } & \multicolumn{2}{c|}{ Total } \\
\hline & \multicolumn{2}{|c|}{ O.A.U } & \multicolumn{2}{c|}{ U.I } & \multicolumn{2}{c|}{ C.U. } \\
\hline Don't know no & Count & $\%$ & Count & $\%$ & Count & $\%$ & Count & $\%$ & Count & $\%$ \\
\hline Yes & 11 & $11.5 \%$ & 3 & $3.1 \%$ & 12 & $12.2 \%$ & 27 & $27.6 \%$ & 53 & $13.6 \%$ \\
\hline & 35 & $36.4 \%$ & 34 & $35.0 \%$ & 10 & $10.2 \%$ & 6 & $6.1 \%$ & 85 & $21.0 \%$ \\
\hline & 50 & $52.1 \%$ & 60 & $61.9 \%$ & 76 & $77.6 \%$ & 65 & $66.3 \%$ & 251 & $64.5 \%$ \\
\hline Total & 96 & $100 \%$ & 97 & 100 & 98 & $100 \%$ & 98 & $100 \%$ & 3.89 & $100 \%$ \\
\hline
\end{tabular}

Source: Field survey 2002

$X 21=14.11 ; X 21=12,59=d f=6 ; p<0.05$

Results in table 2 above indicated that majority of the respondents from all the four universities samples were familiar with the parameters as shown by the "yes" response rate of 50(52.1\%) in OAU, 60(61.9\%) in UI, 76(77.\%) in OOU and 65(66.3\%) in UNAD and on overall "yes" response rate of $257(64.5 \%)$ of all the universities are taken together. The number of responses in the three response categories however vary significantly as indicated by the Chi square analysis carried out $(X 21=14.11 ; X 21=12.59=6 ; p>0.05$, df $p)$ Thus the null hypothesis generated is partly rejected.

The opinion of the students in the four selected universities however do not support this finding. Table 5.8 below contains the responses of the students on their familiarity with NUC parameter for accrediting programmes.

Table 3: Students Responses to Familiarity with Criteria/Parameters for Accrediting Programmes

\begin{tabular}{|l|l|l|l|l|l|l|l|l|l|l|}
\hline Questionnaire & \multicolumn{10}{l|}{ UNIVERSITY } \\
\hline Don't know & O.A.U & \multicolumn{1}{l|}{ U.I } & O.O.U & \multicolumn{1}{l|}{ U.N.A.D } & \multicolumn{2}{l|}{ Total } \\
\hline Not & Count & $\%$ & Count & $\%$ & Count & $\%$ & Count & $\%$ & Count & $\%$ \\
\hline Relevant & 28 & $56 \%$ & 40 & $80 \%$ & 24 & $48 \%$ & 27 & $54 \%$ & 119 & $59.5 \%$ \\
\hline Yes & 3 & $6 \%$ & 4 & $8 \%$ & 11 & $22 \%$ & 7 & $14 \%$ & 25 & $12.5 \%$ \\
\hline & 17 & $38 \%$ & 6 & $6 \%$ & 15 & $30 \%$ & 16 & $32 \%$ & 56 & $28 \%$ \\
\hline Total & 50 & $100 \%$ & 50 & 100 & 50 & $100 \%$ & 50 & $100 \%$ & 200 & $100 \%$ \\
\hline
\end{tabular}

Source: Field survey 2002

$X 2 E=15.21 ; X 21=12.59$ df $6 ; p<0.05$

This result indicates that students are not familiar with the parameter for accrediting programmes.

The extent of their unawareness is suggested by the folio wing proportions of"don't know" responses across the universities. 28(56\%) in OAU, 40(80\%) in UI, 24(48\%) in OOL. 27(54\%) in UNAD and an overall of $119(59.5 \%)$ in all the four universities taken together.

This same trend of opinion of students on familiarity to NUC accreditation parameters observed in their opinions of the adequacy of NUC parameters.

Table 4: Adequacy of NUC Accreditation Exercise Parameters

Response

University

\begin{tabular}{|l|c|c|c|c|c|c|c|c|c|c|}
\hline Questionnaire & \multicolumn{9}{|c|}{ University } \\
\hline Don't know & \multicolumn{2}{|c|}{ O.A.U } & \multicolumn{2}{|c|}{ U.I } & \multicolumn{2}{c|}{ O.O.U } & \multicolumn{2}{c|}{ U.N.A.D } & \multicolumn{2}{c|}{ Total } \\
\hline No & Count & $\%$ & Count & $\%$ & Count & $\%$ & Count & $\%$ & Count & $\%$ \\
\hline Yes & 17 & $17.7 \%$ & 34 & $35 \%$ & 21 & $21.4 \%$ & 30 & $30.6 \%$ & 102 & $26.22 \%$ \\
\hline & - & - & - & - & - & - & 01 & $1 \%$ & 1 & $0.25 \%$ \\
\hline \multicolumn{1}{|c|}{} & - & $82.3 \%$ & 63 & $65 \%$ & & $78.6 \%$ & 67 & $68.4 \%$ & 268 & $73.52 \%$ \\
\hline \multicolumn{1}{|c|}{ Total } & 96 & $100 \%$ & 97 & 100 & 98 & $100 \%$ & 98 & $100 \%$ & 3.89 & $100 \%$ \\
\hline
\end{tabular}

Source: Field survey 2002 
$X 2 E=15.21 ; X 21=12.59$ df $6 ; p<0.05$

Majority of respondents, as shown in table 4.10 agreed that the NUC accreditation exercise parameters are adequate 79(82.3\%) in OAU, 63(65\%) in $\mathrm{UI}, 77(78.6 \%)$ in OOU, 67(68.4\%) in UNAD and an overall of 286(73.52\%) in the four universities taking together. These responses, though have same wend in all the four universities, there is a significant difference across the three responses categories of Don't know", "No" and "Yes" across the four Universities $(\mathrm{X} 21=1275: \S=12.59=\mathrm{df}=6 ; p>0.05)$. With these results, together with the data provided on the familiarity with NUC accreditation parameter, the hypothesis which states that the NUC parameters for acerediting programmes are inadequate to meet the objectives of the academic programmes is rejected and the alternative hypothesis which states that the NUC parameters for accrediting prograrnmes are adequate to meet the objectives of the academic programme is accepted.

\section{Conclusion}

The objective was the examination of the parameter of N.U.C accreditation exercise. The findings indicated that the parameter of N.U.C accreditation is adequate and appropriate. The parameter used for accreditation arc good, bat there is need for adequate funding to the university in order to maximize the dedication of staff to the philosophy and objectives of the programmes. Since this could affect the quality of education and stability of the programmes in the university.

\section{References}

Adamolekun, N.K. (1994): "Higher Education: The Universities", in Akinkugbe, 0.0. (Ed) Nigeria and Education; The Challenges Ahead, The Second Obafemi Awolowo

Foundation Dialogue, (Ibadan: Spectrum Books, Ltd.).

Ade Ajayi, J.F. (2000): "Towards a Culture of Science and Technology", in A.K. Fashina (e.d). Essays in Science Education, (Ibadan: Sam Bookman Publishers), pp. 1-11.

Ake, C. (1994): Democratization of Disempowerment in Africa, (Lagos: Maithouse Press).

Akinkugbe, 0.0. (2001): "The Piper, the Tune and University Autonomy in Nigerian" Social Scientist ,Vol. 4, No. 1, pg; 2-6.

Aldelson, M. (1966): "The System Approach: A perspective". SDC Magazine, № 10.

Alkin, M.C.(1968): Towards An Evaluation Model: A System Approach. Report No. 43, Los

UInl cits 01 Cu1i1iiiuiu, Cciiuc AOL inc siily O1LuiuuuoiL,

Bangura, Y. (1994): Intellectuals, Economic Reform and Social Change: Constraints and Opportunities in the formation ofa Nigerian Technocracy, Dakar: CODESRIA

Monogram Series 1/94.

Blyth W.A.L. (1976): Place, Time and Society Bristol Collus ESL

liorgc, W. It and Gail, N'I.D. (1989). Ed LLcuuonai Research: An Introduction, Fifth Lii Lion. York: Longman).

Boudon, R. (1974): Education, Opportunity and Social Inequality. London: IViley.

Caplow (1983): Managing Organizations CSB Coil. Publications Ltd.

Cuba, E.G. \& Lincoln, V.S.(1989): Fourth Generation Evaluation and Research Methods, (2nd Ed.) (Newburg Park, CA: Sage Publication).

Dore, R. (1976): The Diploma Disease. London: Allen \& Unwin.

Ehindero. O.J. (1986). Curriculum Foundations and Department for NigerianStudents. Lagos Concept Publications Ltd.

Ereto. E. J., (1991j. Leadership and Organizational Performance in Selected South-Western Nigerian Universities. Unpublished PhD Thesis, Obafemi Awolowo University. Ile-lfe.

Erzioni. A. (1960): "Two Approaches to Organizational Analysis - A Critique and a Suggestion", Administrative Science Quarterly, 5:257-278, 1960.

Et.zioni, A. (1964): Modern Organizations. New Jersey: Prentice Hall Inc., 1964.

Haggert, S.A, (1968) livaiuation Alternatives in Education Planning'. Santa Monica, California:The RAND Corporation, D-172338-SMS.

R.L. and Stufilebeam, D.LO. 1969) Planning and Evaluation of State- Administered Programs for the Handicapped' Report to the U.S. Office of Education Bureau of the Handicapped. Columbus, Ohio: Evaluation Centre, Ohio State University.

Ihonvbere, J.O. (1993): Africa in the Post-containment Era, Constraints, Pressures and Prospects for the 21st Century, The Round Table, №. 328, 443-59. 
ISSN 2239-978X

ISSN 2240-0524
Journal of Educational and Social Research MCSER Publishing, Rome-Italy
Vol. 4 No. 6 September 2014 